\title{
PENGEMBANGAN MODEL PEMBELAJARAN BERBASIS MASALAH UNTUK MENINGKATKAN MOTIVASI BERPRESTASI WARGA BELAJAR PROGRAM PENDIDIKAN KECAKAPAN HIDUP
}

\author{
lis Prasetyo* \\ Sutaryat Trisnamansyah**
}

\begin{abstract}
This study aimed to develop a model of problem-based learning to increase the achievement motivation of the participants of life skills education programs and to examine the effectiveness of the learning model in accelerating the achievement motivation. The research conducted in Kemloko, Srimartani village, Piyungan Sub-district, Bantul, in the Province of Yogjakarta, employed research and development approach in an oyster mushroom cultivation training. The try out of the model used experimental design (quasi experiment - a non equivalent control group design), with 20 people for each group. The results showed that there is no difference in achievement motivation scores before and after training $(p=0.385)$ in the control group after an average of different test score achievement motivation, while there are differences in achievement motivation scores before and after training $(p=0.001)$. Effectiveness test also showed significant differences between the control and treat-ment groups $(p=0.012)$ so that the problem-based learning model is effective to increase achievement motivation compared to the conventional models (model control class).
\end{abstract}

Keywords: achievement motivation, entrepreneurship, life-skill education, problem based learning

\begin{abstract}
Abstrak
Penelitian ini bertujuan untuk mengembangkan model pembelajaran berbasis masalah untuk meningkatkan motivasi berprestasi warga belajar program pendidikan kecakapan hidup dan untuk mengetahui efektivitas model pembelajaran dalam meningkatkan motivasi berprestasi. Metode penelitian yang digunakan dalam penelitian ini adalah Research \& Development (R\&D). Penelitian dilaksanakan di Dusun Kemloko Desa Srimartani Kecamatan Piyungan Kabupaten Bantul, Provinsi Daerah Istimewa Yogyakarta, dalam pelatihan budi daya jamur tiram. Tahap uji coba model menggunakan desain eksperimental (quasi experiment - non equivalent control group design), dengan masing-masing anggota kelompok berjumlah 20 orang. Hasil penelitian menunjukkan: pada kelompok kontrol setelah dilakukan uji beda rata-rata skor motivasi berprestasi tidak terdapat perbedaan skor motivasi berprestasi sebelum dan sesudah pelatihan $(p=0,385)$, pada kelompok treatment terdapat perbedaan skor motivasi berprestasi sebelum dan setelah pelatihan $(p=0,001)$. Uji efektivitas juga menunjukkan perbedaan signifikan antara kelompok kontrol dan kelompok treatment $(p=0,012)$ sehingga disimpulkan model pembelajaran berbasis masalah efektif untuk meningkatkan motivasi berprestasi dibandingkan model lain (model kelas kontrol).
\end{abstract}

Kata-kata Kunci: kewirausahaan, motivasi berprestasi, pendidikan kecakapan hidup, pembelajaran berbasis masalah.

\section{PENDAHULUAN}

Jumlah pengangguran di Indonesia kian hari semakin bertambah seiring dengan semakin mening-katnya jumlah penduduk usia produktif setiap

* Dosen jurusan Pendidikan luar Sekolah Fakultas IImu Pendidikan Universitas Negeri Yogyakarta

${ }^{* *}$ Dosen Sekolah Pascasarjana Universitas Pendidikan Indonesia tahunnya, baik itu usia produktif yang terdidik ataupun yang tidak terdidik. Untuk pengangguran terdidik, diperkirakan setiap tahunnya Indonesia memproduksi sekitar 300.000 sarjana dari 2.900 perguruan tinggi dan pada bulan Februari 2005 jumlah sarjana yang mengganggur mencapai 385.400 orang, jumlah ini 
melonjak dua kali lipat empat tahun kemudian yaitu bulan Februari 2009 menjadi 626.600 orang (www. mediaindonesia.com).

Data lain menunjukkan bahwa angkatan kerja nasional berdasarkan survey Badan Pusat Statistik (BPS) Februari 2007 mencatat pengangguran 10.547 .900 orang $(9,75 \%)$, sedangkan pengangguran intelektual tercatat 740.206 orang atau $7,02 \%$. Hasil survei serupa pada Februari 2008 , total pengangguran sebanyak 9.427 .610 orang atau menurun 1,2\% dibanding Februari 2007; sementara itu pengangguran intelektual mencapai 1.461 .000 orang $(15.5 \%)$ atau meningkat 1,02\% dari tahun 2007 (Mangkuprawira, 2008).

Terbatasnya lapangan pekerjaan menyebabkan pemerintah harus mengembangkan berbagai alternatif solusi pemecahan agar penduduk usia produktif yang belum memiliki pekerjaan tetap memiliki produktivitas dengan menghasilkan produk-produk atau kegiatan usaha yang memiliki nilai ekonomis tinggi dan laku dipasaran. Untuk mencapai hal tersebut, program-program pembinaan kewirausahaan bagi penduduk yang menganggur merupakan salah satu cara yang tepat saat ini. Mengutip pendapat David Mike Dallen seorang ahli ekonomi yang menyatakan bahwa suatu negara baru menjadi makmur bila jumlah entre-preneurnya paling sedikit dua persen dari jumlah penduduknya. Sebagai contoh Amerika Serikat pada tahun 1983 jumlah entrepreneurnya mencapai 2,14 persen, dan Singapura pada tahun 2005 jumlah entrepreneurnya mencapai 7,2 persen, sedangkan di Indonesia pada tahun 2006 baru mencapai 0,18 persen (www.kabar.in).

Beberapa tahun terakhir ini, pemerintah telah melakukan berbagai upaya pengembangan program kewirausahaan. Salah satu diantaranya adalah kebijakan program pendidikan nonformal melalui pendidikan kecakapan hidup (life-skills) melalui Departemen Pendidikan Nasional baik dalam jalur pendidikan formal maupun pendidikan nonformal. Khusus untuk jalur pendidikan nonformal, program-program pendidikan kecakapan hidup yang gencar dilaksanakan antara lain program Kewirausahaan Usaha Mandiri untuk Keaksaraan Fungsional, program Kewirausahaan Desa dan Kewirausahaan Perkotaan untuk Kejar paket B dan C dan lain sebagainya, program Desa Vokasi, Program Bantuan Kursus dan Keter-ampilan Kreatif, Program Pendidikan Kewirausahaan Masyarakat dan sebagainya.

Dari hasil penelitian yang dilakukan oleh penulis terkait dengan implementasi program-program berbasis kewirausahaan tersebut, penulis banyak menemukan fakta yang menggambarkan rendahnya mutu implementasi program di masyarakat, salah satunya adalah tidak terpenuhinya standar kompetensi keca-kapan hidup warga belajar. Secara konseptual, program pendidikan kecakapan hidup bertujuan untuk me-ningkatkan kompetensi warga belajar, yang terbagi atas dua jenis kompetensi yaitu kompetensi generik dan kompetensi spesifik. Kompetensi generik meliputi kompetensi kepribadian dan sosial, kecakapan kepribadian meliputi kecakapan mengenal diri (self awareness) dan kecakapan berfikir rasional (thinking skills), sedangkan kecakapan sosial atau interpresonal meliputi kecakapan komunikasi dan empati, dan kecakapan bekerjasama.

Data penelitian pendahuluan menunjukkan bahwa proporsi materi kecakapan personal-sosial dan vokasional-akademis yaitu (13\% : $87 \%)$ yang berarti materi program lebih banyak didominasi oleh materi kecakapan vokasional keterampilan tertentu. Kondisi ini memiliki keterkaitan dengan hasil penelitian yang dilakukan oleh penulis dalam assessment tingkat motivasi berprestasi warga belajar program pendidikan kecakapan hidup di Daerah Istimewa Yogyakarta yang menunjukkan bahwa hanya 1,4\% warga belajar memiliki motivasi berprestasi sangat tinggi, 31,62\% warga belajar yang memiliki motivasi berpestasi tinggi, $45,59 \%$ dengan motivasi berprestasi sedang, $16,18 \%$ motivasi berprestasi rendah, sedangkan sisanya se-besar $5,15 \%$ memiliki motivasi berprestasi sangat rendah (Prasetyo, 2010).

Berdasarkan pada konseptualisasi yang dikemukakan oleh McClelland tentang motivasi berprestasi dan perannya dihubungkan dengan situasi berprestasi, Miner tahun 1980 kemudian menge-mukakan sistem "task-inducement" yang mencakup pencapaian pribadi, yang didefinisikan sebagai keinginan untuk mencapai sesuatu didasarkan pada kemampuan diri dan upaya untuk meningkatkan pengalaman harga diri dan prestasi diri (Miner, 1993 dalam Stewart \& Roth, 2007: 403). Teori tugas motivasi meramalkan bahwa seseorang dengan motivasi berprestasi tinggi akan tertarik pada kewirausahaan karena sifatnya yang melekat pada pekerjaan kewira-usahaan (Miner, 1993 dalam Stewart \& Roth, 2007: 403).

Dalam domain sifat-sifat kepribadian dan kewirausahaan, konsep motivasi berprestasi ( $n$-Ach) telah mendapatkan banyak perhatian. McClelland (1961) menyatakan bahwa individu yang tinggi dalam n-Ach lebih memungkinkan terlibat dalam kegiatan atau tugas yang memiliki tingkat tanggung jawab individu tinggi terhadap hasil, memerlukan keterampilan dan usaha individu, memiliki tingkat resiko yang moderat dan termasuk umpan balik yang jelas pada kinerja jika dibandingkan yang tingkat $n$-Ach rendah (Shane et al, 2003: 263).

Dalam proses menjadi seorang wirausaha, faktor motivasional bukan satu-satunya faktor yang paling berpengaruh terhadap kesuksesan seseorang dalam berwirausaha, seperti diungkapkan oleh Locke (2000).

Motivations are not the only things that influence these transitions. Cognitive factors, including know- 
ledge, skills, and abilities (KSAs), certainly matter. All action is the result of the combination or integration of motivation and cognition (Locke, 2000 dalam Shane, 2003: 275).

Meskipun pendapat di atas menegaskan bahwa motivasi bukanlah satu-satunya faktor yang paling berpengaruh pada kesuksesan dalam berwirausaha, namun pendapat di atas juga menguatkan pendapat peneliti bahwa untuk menjadi seorang wirausahawan memerlukan penguatan faktor kognitif yang meli- puti pengetahuan, keterampilan dan keahlian, yang kemu-dian ditunjang oleh motivasi sehingga keseimbangan antara kompetensi generik dan kompetensi spesifik harus diperhatikan. Dalam upaya untuk meningkatkan kompetensi generik warga belajar yang tertuang dalam karakteristik motivasi berprestasi, dipandang perlu untuk dilakukan pengembangan model pembelajaran yang sesuai karakteristik warga belajar dan karakteristik masalah yang dialami warga belajar.

\section{KAJIAN TEORETIS}

\section{Motivasi Berprestasi dan Kewirausahaan}

Kewirausahaan pada hakikatnya adalah kemam-puan kreatif dan inovatif yang dijadikan dasar, kiat, dan sumber daya untuk mencari peluang menuju sukses. Inti dari kewirausahaan adalah kemampuan untuk menciptakan sesuatu yang baru dan berbeda (create new and different) melalui berpikir kreatif dan inovatif (Suryana, 2003 dalam Muhyi, 2007: 3). Definisi kewirausahaan lainnya dikemukakan oleh Klein, et al. sebagai berikut.

Entrepreneurship is often conceived as innovation, creativity, the establishment of new organizations or activities, or some kind of novelty. Under this conceptualization, entrepreneurship occurs in markets, firms, government, and universities (Slaughter and Leslie, 1997 dalam Klein, et all, 2010: 2).

Wirausaha adalah orang yang memiliki keberani-an untuk melakukan usaha dengan tangannya sendiri, berani untuk menanggung resiko, dan memiliki dedikasi menjalankan bisnis hingga berhasil. Untuk mencapai keberhasilan ini, menurut McClelland (dalam Oswari, 2005: 202) diperlukan orang yang mempunyai (n-Ach) motivasi berprestasi yang tinggi. Kewirausahaan secara lebih luas didefinisikan sebagai proses penciptaan sesuatu yang berbeda nilainya dengan menggunakan usaha dan waktu yang diperlukan, memikul resiko finansial, psikologi, dan sosial yang menyertainya, serta menerima balas jasa moneter dan kepuasan pribadi (Wiratmo, 2001 dalam Oswari, 2005: 202).

Seorang wirausaha memiliki karakteristik pribadi yang menunjukkan perbedaan antara seorang wira-usaha dan bukan wirausaha. McClelland (dalam Oswari, 2005: 202) mengindikasikan ada korelasi positif antara tingkah laku orang yang memiliki motif berprestasi tinggi dengan tingkah laku wirausaha. Beberapa karakteristik orang yang memiliki motivasi berprestasi tinggi antara lain (1) memilih resiko "moderate". Dalam tindakannya memilih melakukan sesuatu yang ada tantangannya namun dengan cukup kemungkinan untuk berhasil. (2) Mengambil tanggung jawab pribadi atas perbuatan-perbuatannya. Artinya kecil sekali kecenderungan untuk mencari "kambing hitam" atas kegagalan atau kesalahan yang dilakukannya. (3) Mencari umpan balik (feedback) tentang perbuatan-perbuatannya. Berusaha melakukan sesuatu dengan cara-cara baru (Oswari, 2005: 203).

International Management System menyebutkan karakteristik pribadi wirausaha (personal entrepreneurial characteristic) sebagai berikut (dalam Oswari, 2005: 204).

1. Kelompok Berprestasi (Achievement Cluster): kreatif, mencari peluang, keuletan, pengambilan resiko, tuntutan atas kualitas dan efisiensi, serta tanggung jawab terhadap pekerjaan.

2. Kelompok Perencanaan (Planning Cluster): menetapkan sasaran, perencanaan dan monitoring yang sistematik, serta mencari informasi.

3. Kelompok Kekuatan (Power Cluster): persuasi dan jejaring, percaya diri.

Banyak penelitian yang dilakukan berkaitan dengan motivasi berprestasi kewirausahaan yang didasarkan pada satu atau dua teori yang berhubungan dengan kebutuhan yang dikemukakan oleh Muray pada tahun 1938.

Pertama McClelland (1961) (dalam Oswari, 2005) mengemukakan fakta bahwa motivasi berprestasi yang tinggi ditandai dengan dorongan untuk melakukan sesuatu lebih baik untuk mencapai suatu prestasi, mempengaruhi seseorang untuk mencari posisi kewirausahaan, yang dipercaya oleh para wirausaha-wan dapat memberikan kepuasan prestasi daripada hanya menempati posisi tertentu.

Berdasarkan pada konseptualisasi yang dikemukakan oleh McClelland (1961) tentang motivasi berprestasi dan perannya dihubungkan dengan 
situasi berprestasi, Miner pada tahun 1980 kemudian menge-mukakan sistem "task-inducement" yang mencakup pencapaian pribadi, yang didefinisikan sebagai keinginan untuk mencapai sesuatu didasarkan pada kemampuan diri dan upaya untuk meningkatkan pengalaman harga diri dan prestasi diri (dalam Stewart \& Roth, 2007: 403). Teori tugas motivasi meramalkan bahwa seseorang dengan motivasi berprestasi tinggi akan tertarik pada kewirausahaan karena sifatnya yang melekat pada pekerjaan kewirausahaan (Miner, 1993 dalam Stewart \& Roth, 2007: 403).

Teori seringkali membuktikan bahwa motivasi berprestasi mendasari komitmen dan ketekunan yang diperlukan untuk berwirausaha, didasarkan pada penilaian meta analisis yang dilakukan oleh Collins, Hanges dan Locke (2004) yang menyimpulkan bahwa motivasi berprestasi secara signifikan berhubungan dengan karir, pilihan, dan kinerja kewirausahaan (Stewart \& Roth, 2007: 403).

Dalam domain sifat-sifat kepribadian dan kewirausahaan, konsep motivasi berprestasi ( $n$-Ach) telah mendapatkan banyak perhatian. McClelland (1961) menyatakan bahwa individu yang tinggi dalam n-Ach lebih memungkinkan terlibat dalam kegiatan atau tugas yang memiliki tingkat tanggung jawab individu tinggi terhadap hasil, memerlukan keterampilan dan usaha individu, memiliki tingkat resiko yang moderat, dan termasuk umpan balik yang jelas pada kinerja jika dibandingkan yang tingkat $n$-Ach rendah (Shane et al, 2003: 263).

Selanjutnya, McClelland (dalam Oswari, 2005) berpendapat bahwa peran wirausaha yang dicirikan memiliki tingkat yang lebih besar pada atribut tugas dan karir lainnya, sehingga ada kemungkinan bahwa orang-orang dengan n-Ach tinggi akan lebih mungkin untuk mengejar pekerjaan kewirausahaan daripada jenis peran lainnya.

Motivasi sangat berpengaruh terhadap proses kewirausahaan. Beberapa motivasi yang berasal dari dalam diri manusia yang memiliki pengaruh terhadap proses kewirausahaan antara lain "achievement motivation (n-Ach), risk taking, tolerance for ambiguity, locus of control, self eficacy, goal setting, vision, desire for independece, passion, and erive" (Shane et al, 2003: 263-268).

Shane et al (2003: 274) berpendapat bahwa kewirausahaan adalah proses yang dimulai dengan pengenalan terhadap kesempatan wirausaha yang diikuti dengan pengembangan ide bagaimana untuk mengejar kesempatan tersebut, evaluasi kelayakan kesempatan, pengembangan produk atau jasa yang akan diberikan pada pelanggan, mencari sumber daya manusia dan sumber keuangan, desain organisasi dan menentukan pelanggan. Di bawah ini adalah gambar model motivasi kewirausahaan dan proses kewira-usahaan.

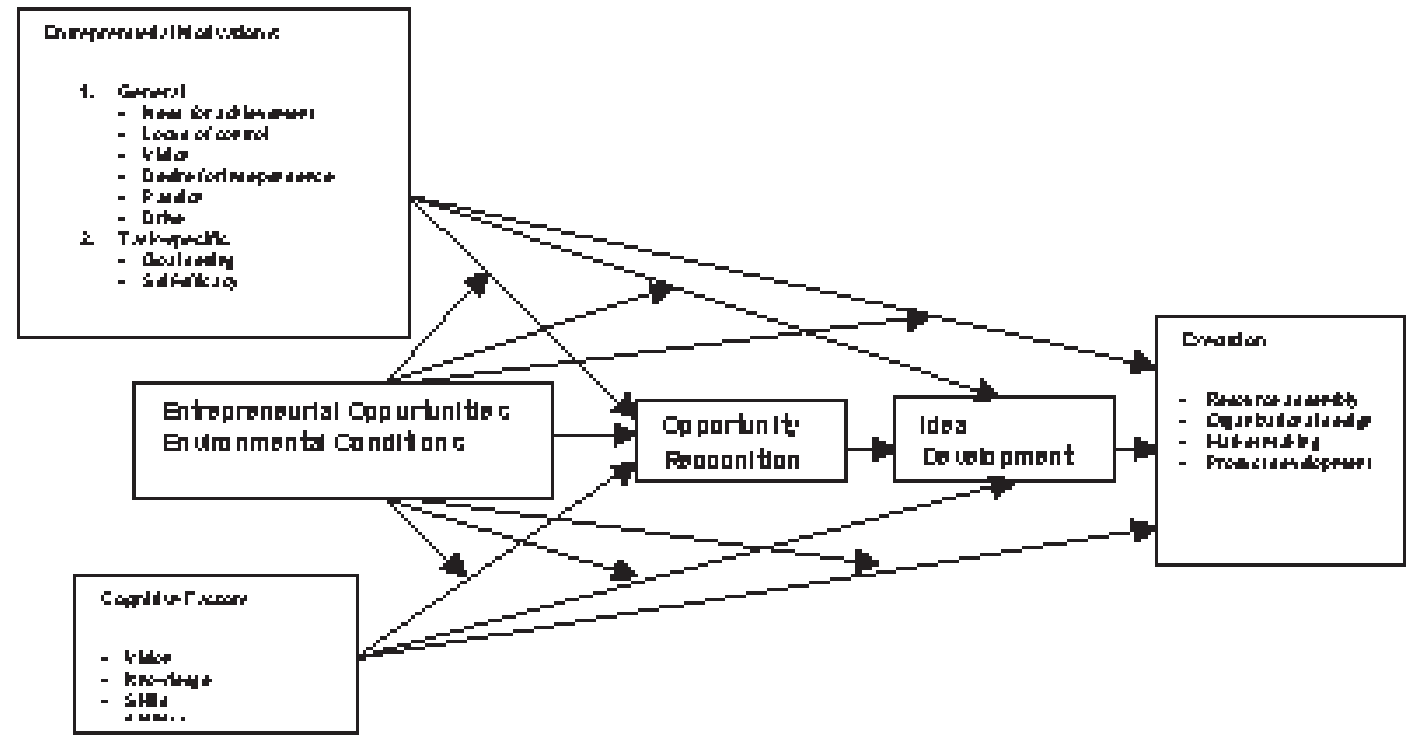

Sumber: S. Shane et al. / Human Resource Management Review 13 (2003) 257-279

Gambar 1. Model Motivasi Kewirausahaan dan Proses Kewirausahaan

Dalam proses menjadi seorang wirausaha, faktor motivasional bukan satu-satunya faktor yang paling berpengaruh terhadap kesuksesan seseorang dalam berwirausaha, seperti diungkapkan oleh Locke (2000).
Motivations are not the only things that influence these transitions. Cognitive factors, including knowledge, skills, and abilities (KSAs), certainly matter. All action is the result of the combination or integration 
of motivation and cognition (Locke, 2000 dalam Shane, 2003: 275).

Pertama, seorang wirausahawan harus memiliki beberapa pengetahuan, terutama yang berkaitan dengan industri dan berbagai teknologi yang relevan dan penting agar menjadi sukses. Wirausaha dapat mempekerjakan orang yang memiliki keahlian khusus yang menjadi kelemahan wirausahawan, tetapi pekerja harus memiliki cukup keahlian untuk mengetahui bahwa apa yang dilakukan adalah benar.

Kedua, seorang wirausaha harus memiliki keahlian (skills). Keterampilan yang diperlukan akan tergantung pada situasi, tetapi keterampilan tersebut dapat mencakup berbagai macam hal seperti penjualan dan tawar-menawar, kepemimpinan, perencanaan, pengambilan keputusan, pemecahan masalah, team building, komunikasi, dan manajemen konflik.

Ketiga, pengusaha perlu memiliki kemampu-an yang diperlukan, termasuk inteligensi. Kemampuan (knowledge, skills, dan abilities) yang diperlukan seorang wirausaha untuk mengembangkan visi yang baik, termasuk strategi organisasi dan membawanya pada kesuksesan.

Motivation helps the entrepreneur to acquire such (knowledge, skills, and abilities) in the first place and provide the impetus and energy to implement the needed actions. The human capital literature in entrepreneur-ship" (e.g., Bates, 1990; Schoonhoven, Eisenhardt, \& Lyman, 1990) "has begun to show the effect of certain types of knowledge and skills on the start-up and resource assembly parts of this proces"s (Shane, 2003: 275)

Upaya Meningkatkan Motivasi Berprestasi melalui Pembelajaran Berbasis Masalah

Hasil penelitian yang dilakukan penulis pada tahun 2010 terkait dengan tingkat motivasi berprestasi warga belajar program pendidikan kecakapan hidup, diperoleh beberapa komponen pola berpikir prestasi yang masih dianggap lemah dan perlu ditingkatkan antara lain.

Pertama, menentukan tujuan. Hal ini dapat dilihat dari persepsi warga belajar yang beranggapan bahwa hari-hari warga belajar selama ini selalu berganti tanpa menghasilkan sesuatu. Implementasi rasa "nrimo" yang terlalu besar ditandai dengan kecenderungan untuk menikmati hidup apa adanya tanpa berupaya untuk merencanakan sesuatu yang dapat memberikan perubahan pada kehidupan warga belajar. Bahkan ketika bekerja pun warga belajar tidak mempertimbangkan efisiensi waktu sehingga banyak waktu terbuang sia-sia hanya untuk mengerjakan sesuatu yang dampaknya tidak terlalu besar bagi hidup warga belajar.

Kedua, tanggung jawab individu. Dapat dilihat dari pendapat warga belajar yang merasa nyaman jika hanya berposisi sebagai bawahan. Warga belajar tidak mau ditunjuk sebagai pemimpin karena tanggung jawabnya yang besar, dan tidak mau disalahkan jika terjadi hal yang buruk ketika diberi tanggung jawab. Bahkan untuk pekerjaan sendiri terkadang warga belajar lebih menyukai menunda pekerjaan dan tidak segera menyelesaikan pekerjaannya ketika ada waktu luang.

Ketiga, keberanian warga belajar untuk mengambil resiko. Warga belajar selalu memiliki ke-takutan ketika akan melakukan usaha atau berwira-usaha misal selalu takut jika barang yang dihasilkan tidak laku atau tidak diminati oleh konsumen, padahal warga belajar belum pernah mencobanya.

Komponen berikutnya adalah hubungan antar-individu yang dirasa masih lemah dan perlu ditingkatkan yaitu menemukan dukungan positif dari orang lain. Kuatnya kebutuhan untuk berafiliasi warga belajar sangat terlihat di sini, di mana sebagian besar warga belajar sangat mementingkan berhubungan baik dengan orang lain meskipun orang tersebut merugikan. Bahkan ketika rekannya tidak mampu bekerja dengan baik, warga belajar akan mempertahankannya daripada harus mempekerjakan atau bekerja dengan orang lain yang tidak dekat dengan warga belajar tetapi sangat ahli.

Berangkat dari hasil penelitian tersebut, muncul-lah suatu gagasan untuk mengembangkan suatu model pembelajaran yang tidak saja mampu meningkatkan motivasi berprestasi, namun juga meningkatkan kemampuan warga belajar untuk menyelesaikan masalah dan memiliki keterampilan untuk bekerja dalam kelompok.

Model pembelajaran berbasis masalah ini didasarkan pada asumsi yang disimpulkan dari pendapat beberapa ahli seperti McClelland, Miner, Collins, dan lainnya yang menyatakan adanya hubungan yang kuat antara motivasi berprestasi dan kewirausahaan. Dalam domain sifat-sifat kepribadian dan kewirausahaan, konsep motivasi berprestasi (n-Ach) telah mendapatkan banyak perhatian. McClelland (1961) menyatakan bahwa individu yang tinggi dalam n-Ach lebih memungkinkan terlibat dalam kegiatan atau tugas yang memiliki tingkat tanggung jawab individu tinggi terhadap hasil, memerlukan keterampilan dan usaha individu, memiliki tingkat resiko yang moderat dan termasuk umpan balik yang jelas pada kinerja jika dibandingkan yang tingkat $n$-Ach rendah (Shane et al, 2003: 263).

Model pembelajaran berbasis masalah untuk meningkatkan motivasi berprestasi dilandasi oleh beberapa aliran filsafat antara lain mengenai karakteris-tik warga belajar dilandasi filsafat pragmatisme 
dan filsafat rekonstruksionalisme, dalam pandangannya tentang pendidik dilandasi oleh filsafat pragmatis, progresivisme, dan eksistensialisme, terkait tujuan pendidikan dilandasi filsafat pragmatisme dan progresivisme, tentang metode pembelajaran dilandasi filsafat pramatisme dan progresivisme, di samping itu, pandangan filsafat humanistik banyak melandasi model pembelajaran ini.

Landasan psikologis yang mewarnai model pembelajaran ini adalah psikologi humanistik. Peran pendidik dalam setting humanistik adalah menjadi fasilitator, penolong, dan rekan dalam proses belajar. Pendidik bukan hanya menyampaikan informasi, tetapi menciptakan suasana belajar. Ketika menjadi fasilitator, pendidik harus meyakini bahwa peserta didiknya bertanggung jawab atas proses bejalar. Penghargaan dan perhatian terhadap pengembangan kemampuan peserta didik merupakan ciri pendidik humanistik sejati.

Sedangkan teori belajar yang melandasi model pembelajaran ini adalah teori belajar konstruktivistik, teori belajar "experiential learning", dan teori belajar "andragogy". Para teoretis konstruktivisme percaya bahwa pengetahuan tidaklah absolut, melainkan dibangun oleh warga belajar berdasarkan pada penge-tahuan sebelumnya dan seluruh tinjauan mengenai dunia. Para ahli konstruktivisme juga meyakini bahwa warga belajar membangun pengetahuan yang cenderung diperoleh melalui proses belajar. Dengan demikian, suatu pemahaman berasal dari interaksi dengan lingkungan, pembelajaran yang merangsang konflik kognitif, pengetahuan yang muncul ketika warga belajar mendiskusikan situasi sosial, dan mengevaluasi pemahaman individu.

Hubungan dekat dengan pembelajaran berbasis masalah mungkin ditemukan dalam karya pragmatis Dewey (1938) dalam (Savin, 2004:31), yang menekan-kan pada kapasitas manusia untuk merekonstruksi pengalaman dan kemudian memaknainya.

Pembelajaran experiential merupakan pem-belajaran orang dewasa yang harus didasarkan pada pengalaman warga belajar, di mana pengalaman menjadi sumber yang sangat bernilai. Ketika orang dewasa terampil dalam belajar, maka orang dewasa tersebut memiliki kemampuan untuk belajar sepanjang hayat.

Knowles et. al. (1998) mengajukan teori tentang belajar untuk orang dewasa yang disebut andragogy. Constructivism and Androgogy are similar in stressing ownership of the learning process by learners, experiential learning and a problem-solving approach to learning (Knowles et al., 1998 dalam Huang, 2002:34).

Brookfield (1995) mengeksplorasi empat proses pembelajaran orang dewasa antara lain. Pertama, self-directed learning focuses on the process by which adults take control of their learning. Kedua, critical re- flection is a form and process. of learning how adults think contextually and critically. Ketiga, experiential learning is such that adult teaching should be based on adults' experiences. Keempat, learning to learn is very crucial for adult development. (Huang, 2002:29).

Keterkaitan antara model pembelajaran berbasis masalah dengan upaya peningkatan motivasi berpres-tasi didasari pada pandangan Maslow dan Rogers, yang memandang bahwa pendidikan sebagai alat pengem-bangan aktualisasi diri dan pemfungsian individu secara penuh. Tujuan akhir pendidikan menurut Maslow adalah aktualisasi diri atau membantu orang menjadi yang terbaik.

Berdasarkan pada hierarki kebutuhan Maslow, kebutuhan akan berprestasi terletak antara kebutuhan akan penghargaan dan kebutuhan akan aktualisasi diri, yang ditandai dengan perilaku inidividu yang menunjuk-kan orientasi tinggi antara lain bersedia menerima resiko yang relatif tinggi, keinginan untuk mendapatkan umpan balik tentang hasil kerja, dan keinginan menda-patkan tanggung jawab pemecahan masalah.

Maslow sebagai tokoh utama teori kebutuhan menyatakan bahwa kebutuhan-kebutuhan manusia sepanjang hidupnya bersifat instinktif yang mengaktif-kan dan mengarahkan perilaku manusia, meskipun demikian perilaku yang digunakan tersebut sifatnya dipelajari (Yusuf \& Nurihsan, 2008: 156). Dengan demikian, untuk mencapai pada tahap kebutuhan aktualisasi diri, seseorang harus meraihnya dengan cara dipelajari (belajar), baik belajar secara mandiri mau-pun secara berkelompok untuk kemudian sadar akan kebutuhannya.

Kesadaran manusia akan kebutuhannya berhu-bungan dengan tiga golongan kesadaran yang dikemukakan oleh Freire, yang terdiri dari kesadaran magis, kesadaran naif, dan kesadaran kritis (Fakih, Topamisamang dan Raharjo, 2000: 23). Kebutuhan akan prestasi (need for achievement) merupakan bagian dari kesadaran naif yaitu keadaan yang dikategorikan dalam kesadaran ini adalah lebih melihat 'aspek manusia' menjadi akar penyebab masalah masyarakat.

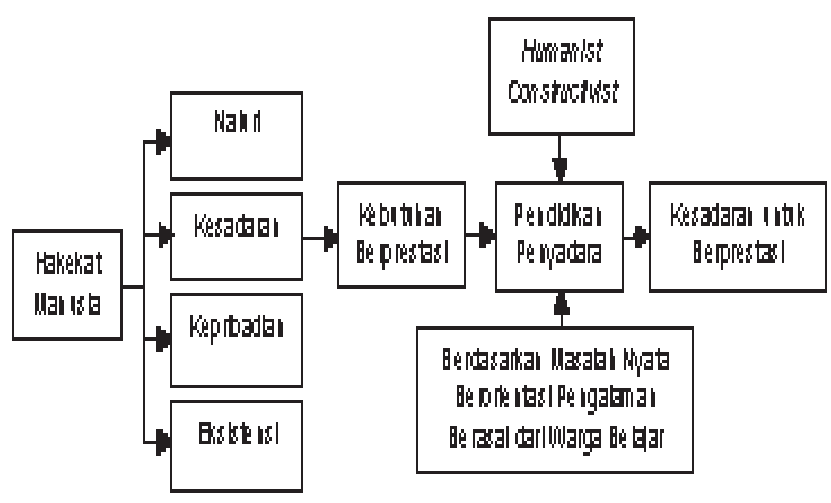

Gambar 2. Alur Penyadaran Kebutuhan Berprestasi melalui Pembelajaran Berbasis Masalah

Jurnal IImiah VISI P2TK PAUD NI - Vol. 6, No.1, Juni 2011 
Tahapan dalam pembelajaran berbasis masalah terdiri atas beberapa tahap antara lain: analisis kebutu-han warga belajar, analisis tujuan dan merumuskan tujuan pembelajaran, analisis karakteristik warga belajar, menentukan isi pembelajaran, menentukan strategi pembelajaran, melaksanakan langkah proses pembelajaran, dan evaluasi program pembelajaran. Di bawah ini adalah desain model pembelajaran berbasis masalah untuk meningkatkan motivasi berprestasi warga belajar program pendidikan kecakapan hidup.

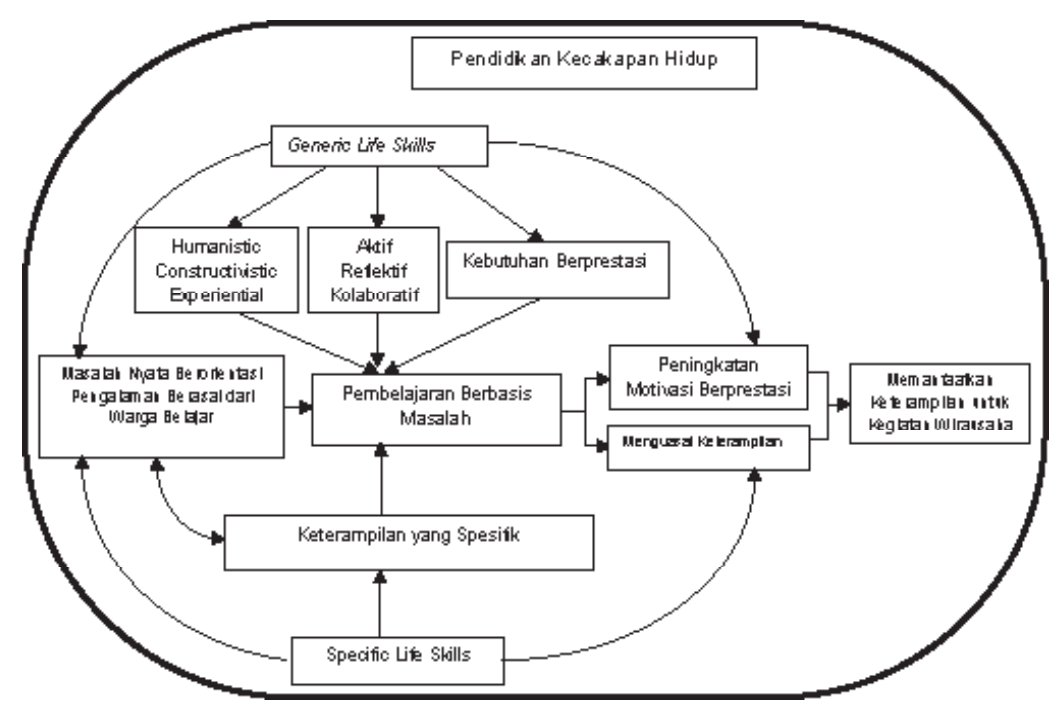

Gambar 3. Model Pembelajaran Berbasis Masalah untuk Meningkatkan Motivasi Berprestasi dalam Pendidikan Kecakapan Hidup

Desain model pembelajaran berbasis masalah di atas menggambarkan mengenai proses pendidikan kecakapan hidup secara komprehensif yang didukung dengan pelaksanaan pembelajaran berbasis masalah dalam proses pembelajarannya. Diawali dengan penentuan kompetensi generik (personal dan sosial) serta kompetensi spesifik (vocational dan akademis). Dengan karakteristik warga belajar yang terdiri dari orang dewasa, materi pembelajaran haruslah berasal dari masalah nyata, berorientasi pengalaman, berasal dari warga belajar dan kegiatannya dilaksanakan secara mandiri dan berkelompok. Di samping itu, keterampilan yang dipelajari juga harus spesifik dan berguna bagi kehidupan warga belajar. Dalam menunjang kecakapan personal dan sosial, pendekatan pembelajaran berbasis masalah didukung dengan pendekatan teori belajar humanistik, konstruktivistik, dan experiential, dilaksana-kan dengan prinsip aktif, reflektif, dan kolaboratif yang dilandasi pada teori kebutuhan untuk berprestasi. Output pembelajaran adalah peningkatan motivasi berprestasi dan penguasaan keterampilan tertentu, sedangkan output program pendidikan kecakapan hidupnya adalah warga belajar memanfaatkan keterampilan yang telah dipelajari untuk kegiatan wira-usaha, baik dilakukan secara perkelompok maupun individu.

\section{METODOLOGI PENELITIAN}

Metode yang digunakan dalam penelitian ini adalah research and development (R\&D) dengan pendekatan kuantitatif, uji coba model pengembangan menggunakan desain eksperimental yaitu nonequivalent group pretest-posttest design. Tahapan dalam penelitian dan pengembangan (R\&D) dalam penelitian ini secara operasional mengadopsi model yang dikembangkan oleh Sugiyono (2008: 298) yang terdiri dari (1) potensi dan masalah; (2) mengumpulkan informasi; (3) pengem-bangan model; (4) validasi model; (5) revisi model; (6) uji coba model; (7) revisi model; (8) uji coba lebih luas; dan (9) revisi model akhir.

Penelitian dilaksanakan pada bulan Juli 2010 sampai Februari 2011 di Provinsi Daerah Istimewa Yogyakarta, bekerja sama dengan Lembaga Pengem-bangan Terpadu Masyarakat (LPTM) Kepak Sayap yang berdomisili di Propinsi D.I. Yogyakarta.

Adapun lokasi penelitian adalah wilayah binaan Lembaga Pengembangan Terpadu Masyarakat "Kepak Sayap" di Dusun Kemloko Desa Srimartani Kecamatan Piyungan Kabupaten Bantul.

Evaluasi motivasi berprestasi dilakukan dengan 
menggunakan angket motivasi berprestasi yang terdiri dari 22 item pertanyaan yang berbentuk pilihan dengan dua alternatif jawaban, skala penilaian menggunakan skala guttman, di mana jawaban yang sesuai skornya 1 (satu) dan jika tidak sesuai skornya 0 (nol). Skor jawaban warga belajar kemudian diakumulasikan dengan maksimal skor adalah 22. Skor penilaian motivasi berprestasi dikelompokkan menjadi lima kelas, antara lain (a) motivasi perprestasi tinggi (skor 20 -22); (b) motivasi berprestasi moderat (16-19); (c) motivasi berprestasi sedang (10-15); (d) motivasi berprestasi cukup rendah (6-9); dan (e) motivasi berprestasi sangat rendah $(<5)$.

Untuk menganalisis tingkat efektivitas model terhadap peningkatan motivasi berprestasi, maka uji statistik yang digunakan adalah uji perbandingan kelompok statistik, uji statistik parametrik mengguna-kan uji t ( $t$ test) sedangkan uji statistik nonparametrik meng-gunakan Wilcoxon Signed Rank Test dan
Man Whitney Test.

Adapun model hipotesis penelitian yang diajukan untuk mengetahui efektivitas model pembelajaran yang dikembangkan adalah: "Model pembelajaran berbasis masalah efektif untuk meningkatkan motivasi berprestasi warga belajar program pendidikan kecakapan hidup dibandingkan model konvensional (kelas kontrol)". Sedangkan hipotesis statistik yang dirumuskan sebagai acuan dalam pengujian beda rata-rata adalah sebagai berikut.

(Ho) : tidak ada perbedaan skor motivasi berperstasi antara kelompok treatment dan kelompok kontrol $\left(\mu_{\text {eksperiment }}=\mu_{\text {kontrol }}\right)$

(Ha) : ada perbedaan signifikan skor motivasi berprestasi antara kelompok treatment dan kelompok kontrol ( $\mu_{\text {eksperiment }}$ ' $\left.\mu_{\text {kontrol }}\right)$.

\section{HASIL PENELITIAN}

\section{Hasil Penelitian}

Penelitian diawali dengan proses identifikasi kebutuhan, sumber, dan hambatan dalam upaya pening-katan motivasi berprestasi. Proses identifikasi kebutuh-an, sumber, dan kemungkinan munculnya hambatan dalam pelaksanaan program dilakukan oleh peneliti dengan menggunakan beberapa metode, antara lain wawancara, studi dokumen, dan observasi.

Tabel 1. Hasil Identifikasi Kebutuhan, Sumber, dan Hambatan

\begin{tabular}{|c|c|c|}
\hline No & Komponen & Keterangan \\
\hline 1. & Demogr afi & $\begin{array}{l}\text { - Daer ah kai Pegunungan } \\
\text { Kidul, ketinggian } 200 \text { M diatas } \\
\text { permukan laut. } \\
\text { Stuktur tan ah berpasir dan } \\
\text { rawan longsor. } \\
\text { Suhu udara antara } 27^{\circ} \text { sampai } \\
33^{\circ} \text { celcius. }\end{array}$ \\
\hline 2. & Willarga Belajar & $\begin{array}{l}\text { - Populasi potensial sebagai } \\
\text { warga belajar program } \\
\text { pendidkan non formal cukup } \\
\text { banyak. } \\
\text { - Jumlah pengangguran sangat } \\
\text { banyak, mencapai } 45,7 \% \text { dari } \\
\text { total jumlah penduduk dalam } \\
\text { satudusun. } \\
\text { Tingkat pendidkan warga } \\
\text { masyaratat rendah. Sebagian } \\
\text { bekerja di sektor informal. } \\
\text { Wilarga masyarakat sangat } \\
\text { sadar bahwa belajar adalah } \\
\text { ibadah, }\end{array}$ \\
\hline
\end{tabular}

\begin{tabular}{|c|c|c|}
\hline No & Komponen & Ket erangan \\
\hline 3. & Fasilitator & $\begin{array}{l}\text { - } \text { Berasal dari BPKB propinsi } \\
\text { DIY. } \\
\text { - Tutor LPTh Kepak Sayap dan } \\
\text { tenaga teknis dari Rumah } \\
\text { Kebun Jamur }\end{array}$ \\
\hline 4. & Pembiayaan & $\begin{array}{l}\text { - } \quad \text { Berasal dari dana mandiri } \\
\text { peneliti. } \\
\text { * luran vuarga belajar. }\end{array}$ \\
\hline 5. & $\begin{array}{l}\text { Fasilitas } \\
\text { Penunjang } \\
\text { Pembelajar an }\end{array}$ & $\begin{array}{l}\text { - Ruangan cukup memadai } \\
\text { ukuran } 4 \mathrm{~m} \times 6 \mathrm{~m} \text {. } \\
\text { - Tidak tersedia meja dan kursi. } \\
\text { Listrk tersedia. }\end{array}$ \\
\hline 6. & $\begin{array}{l}\text { Organisasi } \\
\text { Penyelenggara }\end{array}$ & $\begin{array}{l}\text { - Peneliti dibantu oleh pengelola } \\
\text { LPTM Kepak Sayap dan } \\
\text { Koordinator wuilayah binaan } \\
\text { Dusun Kemloko }\end{array}$ \\
\hline 7. & $\begin{array}{l}\text { Program yang } \\
\text { disepakati }\end{array}$ & $\begin{array}{l}\text { - Pelatihan budi daya jamur } \\
\text { tiram }\end{array}$ \\
\hline
\end{tabular}

Berdasarkan hasil analisis lingkungan dan identifikasi kebutuhan, peneliti kemudian melakukan analisis Kekuatan, Kelemahan, Peluang dan Ancaman (SWOT) dan dilanjutkan dengan analisis pengemba-ngan agar program yang dikembangkan dapat disesuai-kan dengan kondisi lingkungan internal dan eksternal, yaitu dengan melakukan analisis optimalisasi kekuatan untuk meminimalisir kelemahan dan memanfaatkan peluang untuk mengantisipasi ancaman.

\section{Pengembangan Model Pembelajaran Berbasis Masalah}

Model pembelajaran yang dikembangkan dilandasi oleh beberapa aliran filsafat antara lain mengenai karakteristik warga belajar dilandasi filsafat 
pragmatisme dan filsafat rekonstruksionalisme, dalam pandangannya tentang pendidik dilandasi oleh filsafat pragmatis, progresivisme, dan eksistensialisme. Terkait tujuan pendidikan dilandasi filsafat pragmatisme dan progresivisme, tentang metode pembelajaran dilandasi filsafat pragmatisme dan progresivisme, di samping itu, pandangan filsafat humanistik banyak melandasi model pembelajaran ini.

Landasan psikologis yang mewarnai model pembelajaran ini adalah psikologi humanistik. Peran pendidik dalam setting humanistik adalah menjadi fasilitator, penolong, dan rekan dalam proses belajar.

Pendidik bukan hanya menyampaikan informasi, tetapi menciptakan suasana belajar. Ketika menjadi fasilitator, pendidik harus meyakini bahwa peserta didiknya bertanggung jawab atas proses bejalar. Sedangkan teori belajar yang melandasi model pembelajaran ini adalah teori belajar konstruktivistik, teori belajar "experiential learning", dan teori belajar "andragogy".

Para teoretis konstruktivisme percaya bahwa pengetahuan tidaklah absolut, melainkan dibangun oleh warga belajar berdasarkan pada pengetahuan sebelumnya dan seluruh tinjauan mengenai dunia. Para ahli konstruktivisme juga meyakini bahwa warga belajar membangun pengetahuan yang cenderung diperoleh melalui proses belajar, sehingga suatu pemahaman berasal dari interaksi dengan lingkungan, pembelajaran yang merangsang konflik kognitif dan pengetahuan yang muncul ketika warga belajar mendiskusikan situasi sosial dan mengevaluasi pemahaman individu.

Hubungan dekat dengan pembelajaran berbasis masalah mungkin ditemukan dalam karya pragmatis Dewey (1938) dalam (Savin, 2004:31), yang menakan-kan pada kapasitas manusia untuk merekonstruksi pengalaman dan kemudian memaknainya. Pembela-jaran experiential merupakan pembelajaran orang dewasa yang harus didasarkan pada pengalaman warga belajar, di mana pengalaman menjadi sumber yang sangat bernilai, ketika orang dewasa terampil dalam belajar, maka memiliki kemampuan untuk belajar sepan-jang hayat. Knowles mengajukan teori tentang belajar untuk orang dewasa yang disebut andragogy. Constructivism and Androgogy are similar in stressing ownership of the learning process by learners, experiential learning and a problem-solving approach to learning (Knowles et al., 1998 dalam Huang, 2002:34).

Keterkaitan antara model pembelajaran berbasis masalah dengan upaya peningkatan motivasi berprestasi didasari pada pandangan Abraham Maslow dan Carll Rogers, yang memandang bahwa pendidikan sebagai alat pengembangan aktualisasi diri dan pem-fungsian individu secara penuh. Berdasarkan pada hierarki kebutuhan Maslow, kebutuhan akan berprestasi terletak antara kebutuhan akan penghargaan dan aktualisasi diri, yang ditandai dengan perilaku individu yang menunjukkan orientasi tinggi antara lain bersedia menerima resiko yang relatif tinggi, keinginan untuk mendapatkan umpan balik tentang hasil kerja, dan keinginan mendapatkan tanggung jawab pemecahan masalah.

Maslow sebagai tokoh utama teori kebutuhan menyatakan bahwa kebutuhan-kebutuhan manusia sepanjang hidupnya bersifat instinktif yang mengatifkan dan mengarahkan perilaku manusia, meskipun demikian, perilaku yang digunakan tersebut sifatnya dipelajari (Yusuf \& Nurihsan, 2008: 156). Dengan demikian, untuk mencapai pada tahap kebutuhan aktualisasi diri, seseorang harus meraihnya dengan cara dipelajari (belajar), baik belajar secara mandiri maupun secara berkelompok untuk kemudian sadar akan kebutuhannya. Paulo Freire menyebutkan bahwa kebutuhan akan prestasi (need for achievement) merupakan bagian dari kesadaran "naif" manusia, di mana dalam kesadaran ini lebih melihat aspek manusia menjadi akar penyebab masalah masyarakat (Fakih, Topamisamang dan Raharjo, 2000: 23).

Tahapan dalam pembelajaran berbasis masalah terdiri atas beberapa tahap antara lain analisis kebutuh-an warga belajar, analisis tujuan dan merumuskan tujuan pembelajaran, analisis karakteristik warga belajar, menentukan isi pembelajaran, menentukan strategi pembelajaran, melaksanakan langkah proses pembelajaran, dan evaluasi program pembelajaran. $\mathrm{Di}$ bawah ini adalah desain model pembelajaran berbasis masalah untuk meningkatkan motivasi berprestasi warga belajar program pendidikan kecakapan hidup.

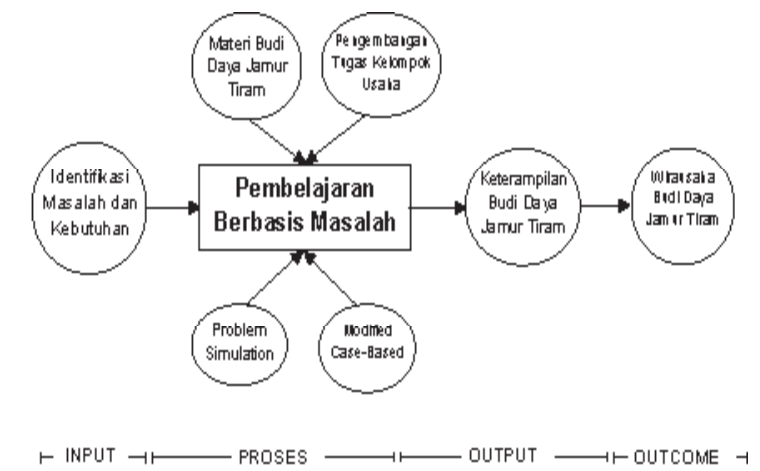

Gambar 4. Model Pembelajaran Berbasis Masalah untuk Meningkatkan Motivasi Berprestasi dalam Pendidikan Kecakapan Hidup

\section{Uji Efektivitas Model}

Uji efektivitas model diawali dengan melakukan 
uji prasyarat analisis untuk mengetahui validitas dan reliabilitas instrumen yang digunakan, serta melakukan uji normalitas data terhadap data tingkat motivasi berprestasi warga belajar (skor pretes dan postes) eksperimen.

Uji validitas menggunakan analisis faktor, berikut adalah hasil pengujian melalui analisis faktor pada instrumen penilaian motivasi berprestasi.

Hasil analisis menunjukkan nilai Kaiser-Meyer-Olkin Measure of Sampling Adequacy pada kotak KMO and Barltlett's Test adalah sebesar 0,524, hasil ini memperlihatkan bahwa instrumen valid karena nilai KMO telah melebihi 0,5. Di samping itu, dapat dilihat dari nilai Barltlett's Test menunjukkan nilai 450,553 dengan nilai signifikansi 0,000 sehingga dapat disimpulkan bahwa instrumen ini telah memenuhi syarat valid di mana $(p<0,05)$.

Uji reliabilitas menggunakan teknik, teknik ini digunakan karena data yang dipakai adalah 1 (satu) dan 0 (nol) dengan kriteria sesuai dan tidak sesuai, jadi jika jawabannya sesuai maka nilainya adalah 1 (satu) dan jika tidak sesuai nilainya 0 (nol).

Tabel 2. Hasil Perhitungan SPSS Reliability Statistics

\begin{tabular}{|c|c|c|c|}
\hline \multirow{5}{*}{$\begin{array}{l}\text { Cronbagh's } \\
\text { Alpha }\end{array}$} & \multirow[t]{2}{*}{ Fart 1} & value & 062 \\
\hline & & N of lteme & $11(a)$ \\
\hline & \multirow[t]{2}{*}{ Fart2 } & Value & .100 \\
\hline & & N of Items & $11(\mathrm{~b})$ \\
\hline & \multicolumn{2}{|c|}{ Total N of Items } & 72 \\
\hline \multicolumn{3}{|c|}{ Correlation Betules rorms } & 352 \\
\hline \multirow{2}{*}{$\begin{array}{l}\text { Spearmar } \\
\text { Erobn } \\
\text { Coefficient }\end{array}$} & \multicolumn{2}{|c|}{ Equal Length } & .521 \\
\hline & \multicolumn{2}{|c|}{ Unequal Length } & 521 \\
\hline \multicolumn{3}{|c|}{ Guttman Split Half Coeffioient } & .521 \\
\hline
\end{tabular}

Dari tabel di atas dapat dilihat bahwa nilai koefisien Guttman Split Half adalah 0,511, di mana nilai ini lebih besar dari 0,5 sehingga dapat disimpulkan bahwa instrumen yang digunakan untuk mengukur motivasi berprestasi adalah reliabel.

Setelah mengetahui instrumen yang digunakan valid dan reliabel, uji prasyarat analisis beikutnya adalah uji normalitas data, teknik yang digunakan dalam pengujian ini adalah menggunakan statistik pengujian Kolmogorov Smirnov dengan SPSS 15. Berikut adalah tabel uji normalitas data.
Pengembangan Model Pembelajaran...

Tabel 3. Hasil Uji Normalitas Data

\begin{tabular}{|l|l|c|c|c|}
\hline \multirow{2}{*}{ No } & \multirow{2}{*}{ Data } & \multicolumn{2}{|c|}{$\begin{array}{c}\text { Kolmogorov } \\
\text { Smirnov }\end{array}$} & \multirow{2}{*}{ Ke } \\
\cline { 3 - 4 } & statistik & signifikanヨ & N ormal \\
\hline 1. & $\begin{array}{l}\text { Kelompok } \\
\text { Kontrol } \\
\text { Pretest }\end{array}$ & 2,958 & 0,052 & N ormal \\
\hline 2. & $\begin{array}{l}\text { Kelompok } \\
\text { Kontrol } \\
\text { Posttest }\end{array}$ & 4,432 & 0,200 & N ormal \\
\hline 3. & $\begin{array}{l}\text { Kelompok } \\
\text { Treatment } \\
\text { Pretest }\end{array}$ & 7,713 & 0,200 & Tidak \\
\hline 4. & $\begin{array}{l}\text { Kelompok } \\
\text { Treatment } \\
\text { Posttest }\end{array}$ & 7,253 & 0,007 & Normal \\
\hline
\end{tabular}

1. Uji Beda Rata-Rata pada Kelompok Kontrol

Skor tingkat motivasi berprestasi warga belajar pada kelompok kontrol diperoleh melalui pretes dan postes pelatihan, hasil pengukuran disajikan pada grafik di bawah ini.

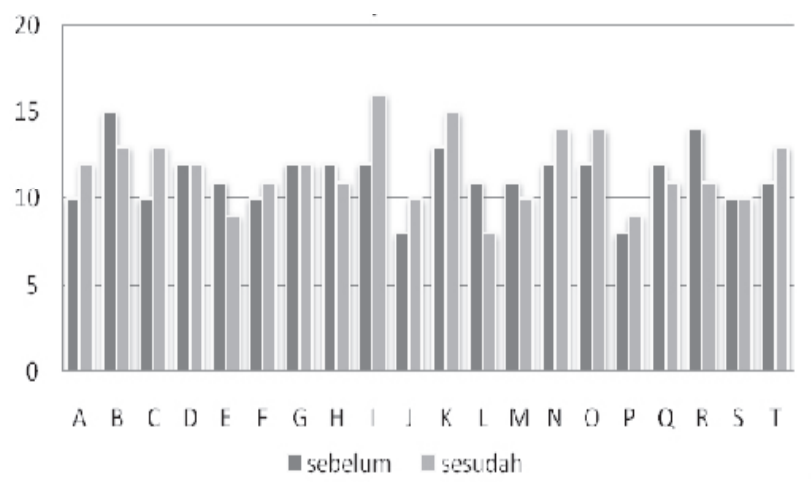

Gambar 5. Grafik Hasil Pengukuran Pretes dan Postes Kelas Kontrol

Uji statistik parametrik dengan uji t $(t$ test) pada kelompok kontrol berdasarkan pada pertimbangan data yang digunakan memenuhi syarat normalitas adapun hipotesis statistik yang diuji dalam analisis ini adalah:

H0 : Tidak ada berbedaan rata-rata skor pretes dan postes

$\mathrm{H} 1$ : Ada perbedaan rata-rata skor pretes dan postes

Tabel 4. Hasil Perhitungan SPSS Uji T

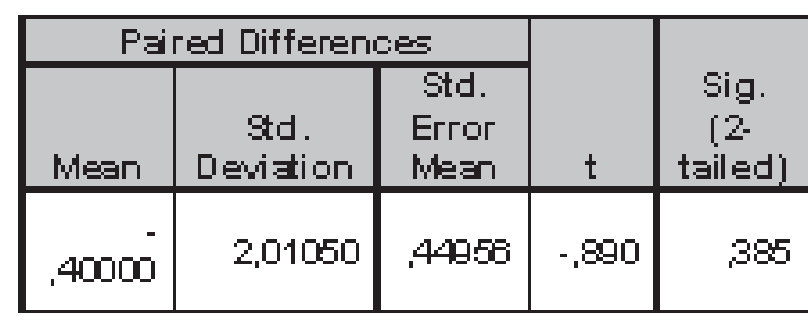

Sumber: data penelitian diolah dengan menggunakan rumus Paired Samples Test dapat diketahui bahwa perbedaan skor antara pretes dan postes adalah $-0,4000$ di mana rata-rata skor pretes adalah 
11,3 dan rata-rata skor postes adalah 11,7. Diketahui nilai $\mathrm{t}$ hitung adalah $-0,890$ dengan signifikansi $p=0,385$ atau $(p>0,05)$, yang berarti $\mathrm{HO}$ diterima dan $\mathrm{H} 1$ ditolak, sehingga dapat disimpulkan bahwa tidak ada perbedaan rata-rata antara skor pretes dan skor postes pada kelompok kontrol.

2. Uji Beda Rata-Rata pada Kelompok Treatment

Skor tingkat motivasi berprestasi warga belajar pada kelompok treatment diperoleh melalui pretes dan postes pelatihan, hasil pengukuran disajikan pada grafik di bawah ini.

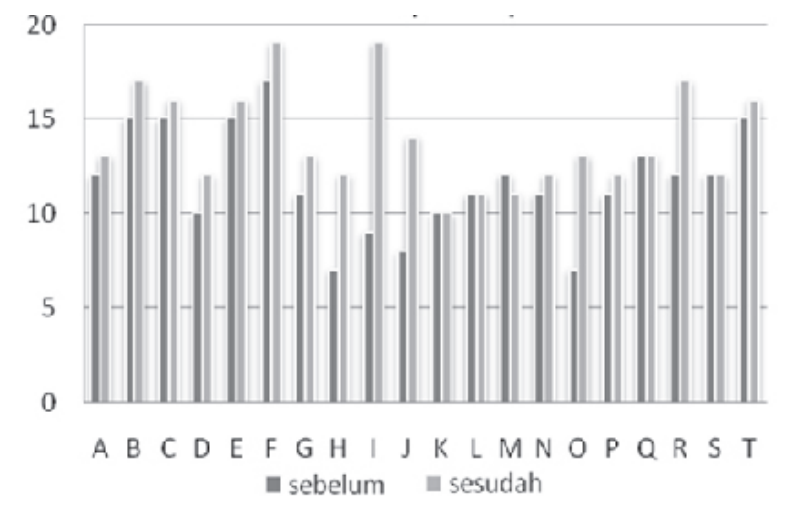

Gambar 6. Hasil Uji Pembeda Kelompok Treatment

Uji beda rata-rata skor pretes dan postes pada kelompok treatment menggunakan uji statistik non-parametrik karena salah satu data tidak memenuhi syarat normalitas. Adapun hipotesis statistik yang diuji dalam uji beda rata-rata ini adalah:

HO: Tidak ada berbedaan rata-rata skor pretes dan postes

$\mathrm{H} 1$ : Ada perbedaan rata-rata skor pretes dan postes

Tabel 5. Wilcoxon Signed Ranks Test Test Statistics(b)

\begin{tabular}{|l|r|}
\hline & $\begin{array}{r}\text { Treatpost } \\
\text {-treatpre }\end{array}$ \\
\hline$Z$ & $-3,349(a)$ \\
\hline $\begin{array}{l}\text { Asymp. Sig. } \\
\text { (2-tailed) }\end{array}$ & .001 \\
\hline
\end{tabular}

a Based on negative ranks.

b Wilcoxon Signed Ranks Test

Hasil pengujian menunjukkan bahwa nilai $Z$ adalah $-3,348$ dengan signifikansi $p=0,001(p<0,05)$ yang berarti $\mathrm{H} 0$ ditolak dan $\mathrm{H} 1$ diterima, sehingga disimpulkan bahwa terdapat perbedaan rata-rata antara skor pretes dan postes pada kelompok treatment.

3. Uji Beda Rata-Rata pada Kelompok Kontrol dan

Treatment (Efektivitas)

Skor tingkat motivasi berprestasi warga belajar pada kelompok kontrol dan treatment untuk mem- ban-dingkan skor postes pelatihan, hasil pengukuran disajikan pada grafik di bawah ini.

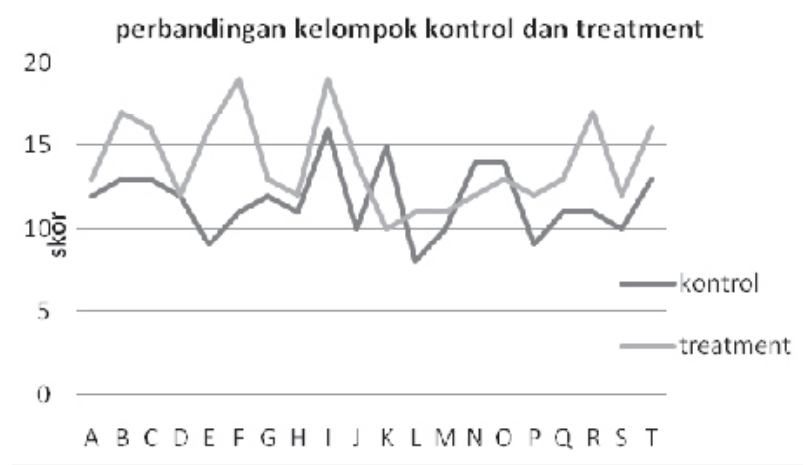

Gambar 7. Grafik Perbandingan Kelompok Kontrol dan Treatment

Uji beda rata-rata skor postes pada kelompok treatment dan kontrol menggunakan uji statistik nonparametrik dengan teknik Mann Whitney Test karena salah satu data tidak memenuhi syarat normalitas. Adapun hipotesis statistik yang diuji dalam uji beda rata-rata ini adalah sebagai berikut.

HO: Tidak ada berbedaan rata-rata skor motivasi berprestasi antara kelompok treatment dan kontrol $\left(\mu_{\text {eksperiment }}=\mu_{\text {kontrol }}\right)$

H1: Ada perbedaan rata-rata skor motivasi berprestasi antara kelompok treatment dan kontrol ( $\mu$ eksperiment '“ $\left.\mu_{\text {kontrol }}\right)$

Tabel 6. Test Statistics (b)

\begin{tabular}{|l|r|}
\hline & Post $t e s t$ \\
\hline Mann-'U' hitrey U & 108,500 \\
\hline 'W' ilcoxon 'Uf' & 318,500 \\
\hline$Z$ & $-2,499$ \\
\hline $\begin{array}{l}\text { Aswmp. Sig. (2- } \\
\text { tailed) }\end{array}$ & .012 \\
\hline $\begin{array}{l}\text { Exact Sig. [2'(1- } \\
\text { tailed Sig.)] }\end{array}$ & .012 (a) \\
\hline
\end{tabular}

a Not corrected for ties.

b Grouping Variable: kelompok

Dengan menggunakan rumus Man Whitney Test dapat diketahui bahwa perbedaan skor antara postes antara kelompok treatment dan kelompok kontrol adalah 2,2 di mana rata-rata skor postes kelompok treatment adalah 13,9 dan rata-rata skor postes kelompok kontrol adalah 11,7 . Diketahui nilai $Z$ hitung adalah $-2,449$ dengan signifikansi $p=0,012$ atau $(p<0,05)$, yang berarti $\mathrm{HO}$ ditolak dan $\mathrm{H} 1$ diterima, sehingga dapat disimpulkan bahwa terdapat perbedaan rata-rata skor motivasi berprestasi antara kelompok treatment dan kelompok kontrol. 


\section{KESIMPULAN}

Hasil penelitian menunjukkan model pembelaja-ran berbasis masalah merupakan model pembelajaran yang tepat digunakan dalam kegiatan pendidikan kecakapan hidup.

Secara empiris, metode ini mampu meningkat-kan motivasi berprestasi warga belajar yang secara teoretis sangat berhubungan dengan jiwa kewira-usahaan yang merupakan modal utama dari keber-lanjutan program.

Model pembelajaran berbasis masalah yang dikembangkan untuk meningkatkan motivasi ber- pres-tasi, secara empiris, mampu meningkatkan skor moti-vasi berprestasi warga belajar program pendidikan kecakapan hidup budi daya jamur tiram. Dibuktikan dengan uji beda rata-rata skor postes motivasi berpres-tasi pada kelompok treatment dan kelompok kontrol diketahui nilai $Z$ hitung $=-2,449$ dengan signifikansi $p=0,012(p<0,05)$ yang berarti H1 diterima sehingga disimpulkan terdapat perbedaan rata-rata skor motivasi berprestasi pada kelompok treatment dan kontrol.

\section{DAFTAR PUSTAKA}

Fakih, M., Topatisamang, R., \& Raharjo, T. (2000). Pendidikan populer, membangun kesadaran kritis. Yogyakarta: Research, Education and Dialogue (ReaD).

Huang, H-M. (2002). Toward constructivism for adult learners in online learning environments. British Journal of Educational Technology, Vol. 33 No 1 p.21-37. Blackwell Publisher Ltd.

Kabar. (2009). Setiap tahun pengangguran intelektual meningkat 20 persen. Diakses pada tanggal 7 Mei 2010 dari http://kabar.in/2009/indonesia-headline/rilis-berita-depkominfo/06/17/ setiap-tahun-pengangguran-intektual-meningkat-20-persen.html.

Klein, P.G., Mahoney, J.T., McGahan, A.M., \& Pitelis, C.N. (2010). Toward a theory of public entrepreneurship. European Management Review. EURAM Macmillan Publisher Ltd. Diakses pada tanggal 6 Mei 2010 dari palgrave-journals.com/ emr.

Mangkuprawira, S. (2008). Pengangguran intelektual vs intelektual penganggur. Diakses pada tanggal 6 Mei 2010 dari http://indosdm.com/ pengangguran-intelektual-vs-intelektual-penganggur.

Media Indonesia. (2009). Pendidikan yang menghina pendidikan. Diakses pada tanggal 6 Mei 2010 dari http://www.mediaindonesia. com/read/2009/08/08/91483/70/13/Pendidikan-yang-Menghina-Pendidikan/9.

Muhyi, H.A. (2007). Menumbuhkan jiwa dan kompetensi kewirausahaan. Makalah Jurusan Administrasi Niaga, Fakultas IImu Sosial dan IImu Politik, Universitas Padjajaran-Bandung. Diakses pada tanggal 6 Mei 2010 dari http:// resources.unpad.ac.id.
Oswari, T. (2005). Membangun jiwa kewirausahaan (enterpreneurship): Menjadi mahasiswa peng-usaha (enterpreneur student) sebagai modal untuk menjadi pelaku usaha baru. Seminar Nasional PESAT 2005, Auditorium Universitas Gunadarma, Jakarta, 23-24 Agustus 2005, ISSN: 18582559

Prasetyo, I. (2010). Assessment tingkat motivasi berprestasi warga belajar program pendidikan kecakapan hidup dan pengembangan model awal pembelajaran berbasis masalah untuk meningkatkan motivasi berprestasi kewira-usahaan warga belajar budi daya jamur tiram di propinsi Daerah Istimewa Yogyakarta. Laporan Penelitian Hibah Disertasi Doktor. Bandung: Lembaga Penelitian Universitas Pendidikan Indonesia. Tidak diterbitkan.

Savin, M., Baden \& Major, C.H. (2004). Foundation of problem-based learning. Maidenhead: Open University Press/SRHE.

Shane, S., Locke, E.A., \& Collins, C.J. (2003). Entrepreneurial motivation. Human Resource Management Review 13, p.257-279. Elsevier Science Inc.

Stewart, W.H., \& Roth, P.L. (2007). A Meta-analysis of achievement motivation differences between enterpreneurs and managers. Journal of Small Business Management 200745 (4), p. 401-421. Syohih, U. (2008). Lingkungan dan pendidikan Indonesia. Diakses pada tanggal 6 Mei 2010 dari http:// nerri-unindra-bio2a.blogspot.com/2008/07/ nilai-nilai-pendidikan-di-indonesia.html.

Yusuf, S.L.N., \& Nurihsan, J. (2008). Teori kepribadian. Bandung: Sekolah Pascasarjana Universitas Pendidikan Indonesia bekerjasama dengan PT. Remaja Rosdakarya. 